\title{
地域別に見たわが国稲作生産性の推移とその要因 一減反開始期以降を対象として一
}

\author{
近藤 功庸（旭川大学） \\ 山本 康貴 (北海道大学大学院農学研究科)
}

\section{1. 課題}

本稿の課題は，減反開始期以降におけるわが国稲作 生産性の推移とその要因を地域別に分析することであ る。すでに近藤・山本 [4] は，新谷 [6] などの見解 を踏まえて,「減反開始期以降, わが国稲作生産性の 伸びは停滞し，その要因は技術変化が停滞するととも に, キャッチ・アップ効果（農家が生産フロンティア に接近すること二技術効率の改善）あ停滞しつつある」 という仮説を設け，この仮説の検証を試みた。その結 果, 稲作生産性の停滞が計量的に確認され, その要因 として技術変化とキャッチ・アップ効果が停滞してい ることが明らかとなった。ただし，近藤・山本 [4] の分析結果は, 分析期間平均值かつ全国平均值での分 析にとどまっている ${ }^{1)}$. そこで本稿では，上記の仮説 が地域別の生産性分析結果から支持されるか否かを 検証することにしたい。

具体的には以下の 3 点を分析する．まず(1)近藤・山 本 [4] と同様の方法により稲作生産性変化を計測し, 稲作生産性（全国平均値）の時系列推移を確認する。 次に(2)道府県別に稲作生産性の変化率を提示し，さら に(3)各道府県の稲作生産性变化を技術变化とキャッ千・ アップ効果に要因分解する.これら(1)〜(3)の分析は, Malmquist 生産性指数の計測を通じて行う。

\section{2. 分析方法 ${ }^{2)}$}

Malmquist 生産性指数 (TFPCH) は生産性 (TFP) 変化を表し，キャッチ・アップ効果 (EFFCH) と技術変化 (TECHCH) に分解できるた め, Malmquist 生産性指数は以下の関係式に要約さ れる.

$$
T F P C H=E F F C H \times T E C H C H
$$

なお，生産性変化を表す Malmquist 生産性指数 (TFPCH)，キャッチ・アップ効果 (EFFCH) 扔よ び技術变化 (TECHCH) の解釈は次のようになる.

$T F P C H>1 （ T F P C H<1 ）$ ならば生産性は上昇 （低下）で, TFPCH=1ならば生産性は変化なしで ある。

$E F F C H>1(E F F C H<1)$ ならばキャッチ・アッ
プ効果はプラス（マイナス）で生産性上昇（低下）に 寄与し， $E F F C H=1$ ならばキャッチ・アップ効果は 変化なしである。

$T E C H C H>1 （ T E C H C H<1 ）$ ならは技術進歩 （技術後退）で，生産性上昇（低下）に寄与し, $T E C H C H=1$ ならば技術変化は変化なしである.

本稿では TFPCH, EFFCH, TECHCH の計測結果 に関し，その変化率（年率）の絶対值が $1 \%$ 以上であ れば明確な変化ありと見なし，1\%未満であれば停滞 （明確な変化なし）と見なす ${ }^{3}$. 以上の Malmquist 生産性指数の計測には線型計画法を用いた。

\section{3. 分析対象地域とデータ}

計測に用いる資料は農林水産省『米及び麦類の生産 費』の県別平均值デー夕であり, 東京都, 大阪府, 神 奈川県, 沖䋥県を除く 43 道府県を分析対象地域とし た。計測期間は 1971 年から 95 年までとした。生産物 は米とし, 生産要素は労㗢, 資本, 土地, 経常財とし た。計測期間の設定およびデー夕の加工方法等に関す る詳細は近藤・山本 $[4]$ を参照されたい。

\section{4. 計測結果}

図 1 は生産性変化およびその要因を全国平均值で時 系列にプロットした図である. 図1より天候の影響な どから稲作生産性の変動が大きく, 明確な上昇トレン ドを見い出すことができない．特に 1980 年と 1993 年 のように深刻な冷害に見舞われた年は生産性の下落が 著しいことが分かる。また，生産性は概衩キャッチ・ アップ効果よりあ技術変化の影響を受けて変化してい る.

表 1 は 43 道府県の稲作生産性, キャッチ・アップ 効果, 技術变化に関する計測結果 (年率, 期間平均値) である ${ }^{4)}$. 表 1 によると, 生産性が上昇した道県は 11 あり, 停滞した府県は29, 低下した県は 3 あった。 生産性変化の要因を見ていくと, キャッチ・アップ効

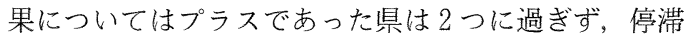
した府県は 41 ，低下した県は皆無であった。ささに 技術変化については技術進歩を示した道県は 10 あり， 


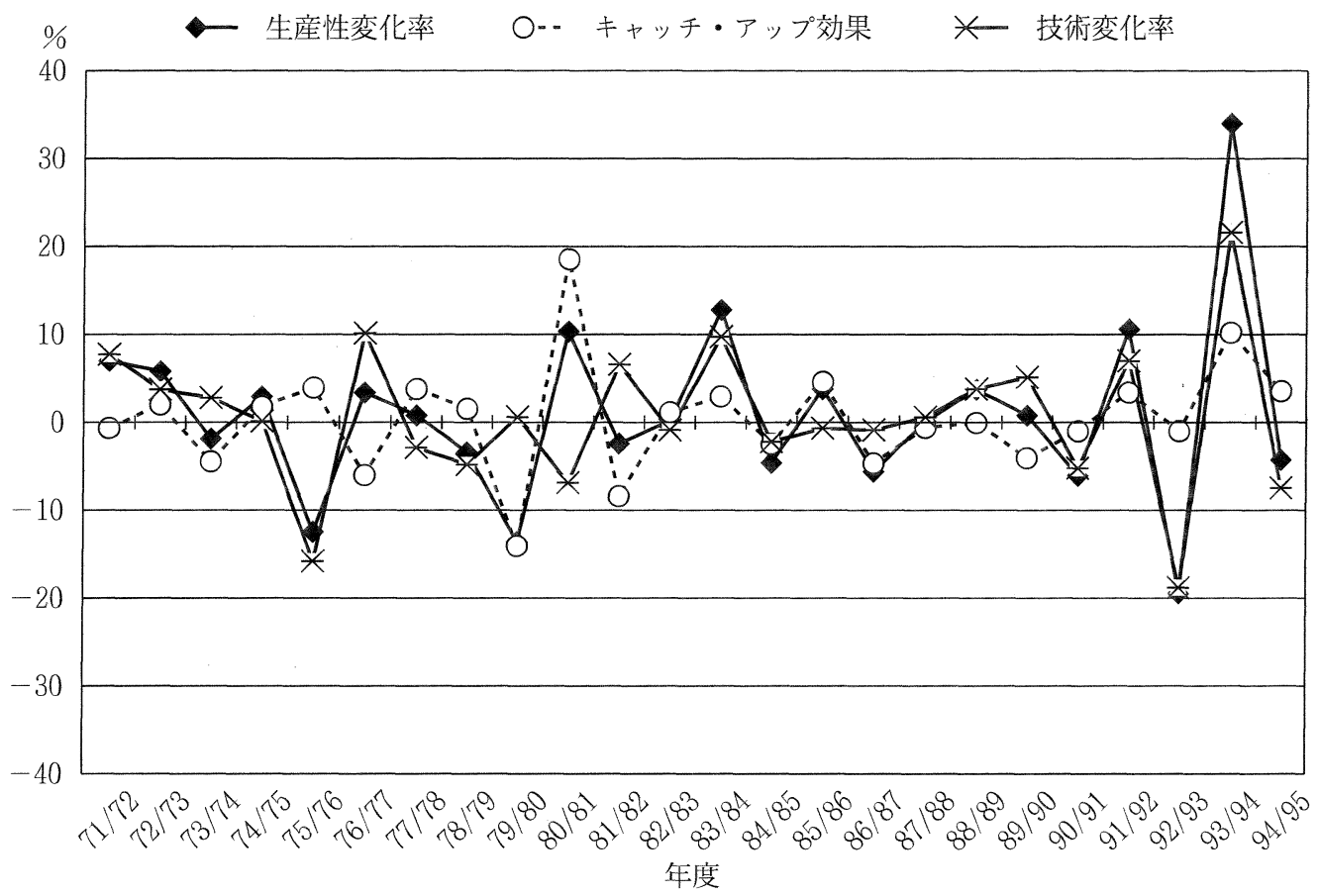

図 1 生産性の時系列変化（全国平均値：年率）

技術水準が停滞した府県は 27 ，技術後退した県は 6 あった5).

表 1 の結果加ら生産性と技術進歩の結果に関し, 地 域別に検討を加えると以下の諸点が読み取れる。

(1)北海道は，生産性上昇率が $3.3 \%$ と全国 1 位で, 技術進歩率も2.1\%で全国 3 位である。

(2)東北では，青森・岩手・宮城の生産性が低下もし くは停滞している6).

(3)北陸では，新潟や富山などで生産性が上昇し，技 術進歩も見られる。

(4)関東・東山では，埼玉と栃木 ${ }^{7)}$ を除き，概水生 産性が停滞している。

(5)東海（岐阜・静岡・愛知・三重）の 4 県では, 静 岡を除く 3 県で, いずれもキャッチ・アップ効果より あ技術進歩が大きく寄与し，生産性が上昇している。

(6)近畿，中国，四国，九州では，福岡・熊本・宮崎 を除いたすべての府県で生産性が停滞している ${ }^{8}$.

以上のように北海道や北陸などごく少数の地域で明 確な生産性の伸びが見られるとはいえ，生産性が停滞 ないしは低下している地域が大半であることが確認さ れた ${ }^{9)}$. 生産性変化の要因である技術変化む生産性変 化自体と同様な動きが確認され，またキャッチ・アッ
プ効果（農家が生産フロンティアに接近すること二技 術効率の改善) は，ほとんどの地域で停滞しているこ 之も確認された。つまり生産性の地域別分析結果から 見ても，「減反開始期以降，わが国稲作生産性の伸び は停滞し，その要因は技術変化が停滞するとともに， キャッチ・アップ効果も停滞しつつある」という仮説 は概㸚支持されたもの之考える。

\section{5. 結論}

本稿の課題は近藤・山本 [4] の分析結果を踏まえ， 減反開始期以降におけるわが国稲作生産性の推移とそ の要因を Malmquist 生産性指数の計測によって地域 別に分析することであった．以下の点が明らかとなっ た.

第一に，稲作生産性（全国平均值）は，天候の影響 などから年次変動が大きく，明確な上昇トレンドを見 い出し難い。また稲作生産性（全国平均値）は，概秝 キャッチ・アップ効果よりあ技術変化の影響を受けて 変化している.

第二に，道府県別稲作生産性の变化率を見る之，北 海道や新潟など一部の地域で生産性上昇率が高いとは いえ，全般に生産性は停滞している。 
表 143 道府県の稲作生産性, キャッチ・アップ効 果, 技術変化の計測結果 (年率)

\begin{tabular}{|c|c|c|c|}
\hline 道府県名 & $\begin{array}{l}\text { 生産性変化 } \\
\text { (1)=(2) + (3) }\end{array}$ & $\begin{array}{c}\text { キャッチ・乎効果 } \\
\text { (2) }\end{array}$ & $\begin{array}{c}\text { 技術変化 } \\
\text { (3) }\end{array}$ \\
\hline 北海道 & 3.3 & 1.1 & 2.1 \\
\hline 青森 & -0.2 & 0.0 & -0.2 \\
\hline 岩手 & -2.0 & -0.5 & -1.5 \\
\hline 宮城 & -0.9 & -0.3 & -0.5 \\
\hline 秋田 & 0.2 & -0.1 & 0.3 \\
\hline 山形 & 1.4 & 0.3 & 1.1 \\
\hline 福島 & -0.9 & 0.3 & -1.2 \\
\hline 茨城 & -1.0 & 0.0 & -1.1 \\
\hline 栃木 & 1.8 & 0.1 & 1.7 \\
\hline 群馬 & 0.3 & 0.3 & 0.1 \\
\hline 埼玉 & 2.7 & -0.1 & 2.7 \\
\hline 千葉 & -0.9 & 0.0 & -0.9 \\
\hline 新潟 & 1.4 & 0.3 & 1.1 \\
\hline 富山 & 1.5 & 0.0 & 1.5 \\
\hline 石川 & -0.2 & -0.2 & -0.1 \\
\hline 福井 & -0.4 & -0.2 & -0.2 \\
\hline 山梨 & -0.7 & -0.1 & -0.5 \\
\hline 長野 & 0.3 & 0.1 & 0.2 \\
\hline 岐阜 & 1.6 & 0.2 & 1.4 \\
\hline 静岡 & 0.3 & 0.1 & 0.3 \\
\hline 愛知 & 2.8 & 0.3 & 2.5 \\
\hline 三重 & 1.4 & 0.2 & 1.2 \\
\hline 滋賀 & 0.5 & -0.1 & 0.6 \\
\hline 京都 & 0.2 & 0.2 & 0.0 \\
\hline 兵庫 & 0.8 & 0.5 & 0.2 \\
\hline 奈良 & -0.2 & 0.1 & -0.2 \\
\hline 和歌山 & 0.1 & 0.2 & -0.1 \\
\hline 鳥取 & 0.3 & 0.5 & -0.2 \\
\hline 島根 & -0.3 & 0.6 & -1.0 \\
\hline 岡山 & 0.9 & 0.5 & 0.4 \\
\hline 広島 & 0.7 & 0.4 & 0.3 \\
\hline 山口 & 0.8 & 0.4 & 0.4 \\
\hline 徳島 & 0.7 & 0.5 & 0.2 \\
\hline 香川 & 0.9 & 0.4 & 0.5 \\
\hline 愛媛 & -0.1 & -0.2 & 0.1 \\
\hline 高知 & 0.6 & 0.3 & 0.2 \\
\hline 福岡 & 1.7 & -0.3 & 2.0 \\
\hline 佐賀 & -0.4 & -0.1 & -0.3 \\
\hline 長崎 & 0.6 & 0.9 & -0.2 \\
\hline 熊本 & -1.2 & 0.0 & -1.3 \\
\hline 大分 & -0.9 & 0.2 & -1.1 \\
\hline 宮崎 & 1.5 & 1.2 & 0.3 \\
\hline 鹿児島 & -0.2 & 0.4 & -0.6 \\
\hline 平均(注) & 0.4 & 0.2 & 0.2 \\
\hline
\end{tabular}

注 : 43 道拊県の平均值は近藤・山本 [4] の第 1 表と同じ.
第三に，道府県別に稲作生産性变化を技術变化とキャッ チ・アップ効果に要因分解して見ると，北海道や新潟 など一部地域で技術進歩が生産性上昇に大きく貢献し ているとはいえ，全般に技術変化もキャッチ・アップ 効果も停滞している.

つまり生産性の地域別分析結果から見ても，「減反 開始期以降，わが国稻作生産性の伸びは停滞し，その 要因は技術変化が停滞するととあに，キャッチ・アッ プ効果も停滞しつつある」という仮説は概䄪支持され たものと考える.

注 1）本稿は近藤・山本 [4] と同じ分析方法およびデー夕 を用いていることから，一見内容的に近藤・山本 [4] 之同じ印象を持たれるかもしれないが, 近藤・山本 [4] の分析結果は, わが国稲作生産性を分析期間平均 值かつ全国平均值のみで, 時期別 - 地域別の分析結果 については全く検討されていない, そのため, 本稿は 自然科学でいう「第二報」に相当するあのであり, 新 たにオリジナルな実証分析結果を提示した論文である 点に注意されたい。

2) Malmquist 生産性指数の詳細な分析方法は近藤・山 本 [4] を参照されたい.

3）何\%以上を変化ありとするかは, 統計的検定で有意水 準を何\%とするかに類似した問題と言えよう。本稿で 分析対象とした 43 道府県のうち，半分以上を占める 29 府県の年平均变化率は絶対值で $1 \%$ に達しておら ず，また 43 道府県全体の年平均变化率は $0.4 \%$ にと どまっている. 全体の年平均変化率 $0.4 \%$ を上回る值 という観点加ら $0.5 \%$ を基準とすることあ当初は考え たが, 近藤・山本 [4] と同じく, 本稿でもより厳し い基準である $1 \%$ を変化ありなしの判定基準とした。

4）本稿の計測期間は 25 年間にわたり，その間に生じた 地域間の人口移動や産業構造の変化等が稲作生産性に 影響を及汸した可能性もある。この点の解明には，期

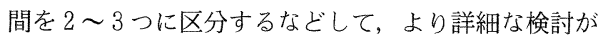
必要であるが，今回はそこまでの分析には至らなかっ た.

5）今回の分析では，なぜ生産性が停滞していたかの理由 なり原因までを明示的に取り込んだ分析までには至ら なかった。

6）東北農区を分析対象とした草获［5] では稲作におけ る機械化の進展により労働生産性の上昇が確認された が，機械化を促した賃金率の上昇は不十分な肥培管理 之有機肥料の投入減少をもたらしたため, 収量变動の 增大につながったことを明らかにした．この傾向は全 国的に見られるが，特に東北農区で顕著であることを 指摘している.

7）技術変化率が年平均 $2 \%$ 以上の伸びを示している埼玉 と愛知に付言しておきたい。この 2 県は各年度の技術 効率の結果を見ると 1976 年以外は生産フロンティア 
上にない。技術効率の 25 年間の平均值は埼玉が 0.845 , 愛知が 0.835 で, 両県とも全国平均值 0.856 よ りあ低いことから, 両県が生産フロンティアを上方シ フトさせたわけではない，年によって異なるが, 両県 の生産フロンティア上の参照集合は, 北海道や新潟で ある、つまり，参照集合となっている北海道や新潟の 生産点が上方に移動したため, 埼玉・愛知屯高い技術 進歩率が計測されたものと推察される。このように本 稿の計測結果はある時点の技術「水準」ではなく, 時 点間の技術「変化率」で示されているため, 計測結果 の解积に注意をされたい.

8）九州の稲作に関し, 甲斐 [3] は良食味米生産の取り 組みが遅れていたことを指摘している. その理由とし て温暖な気象条件により米麦二毛作体系の水田利用が なされ，コシヒカリのような良食味米を生産する場合, 早期の作付けが必要となり, 前作である麦の栽培が困 難となるため, 米単作では水田単位面積当たり収益が 減少するという経済的背景を指摘している，また，本 稿の計測結果において近畿以西で生産性上昇率が最も 高い福岡は, 近畿以西有数の米産地である.

9）農区別に労㗢生産性とTFPをインデックス・ナンバー・ アプローチで分析した土井 [1] の結果では, 本稿と 一部分析期間が重なっている1969 79 年において北 海道の TFP 上昇率（複利成長率）が $2.6 \%$ で最も高 く, 次いで北陸 (2.0\%), 関東 (1.7\%), 東海 (1.7\%), 東北 (1.6\%) となっており, 近畿以西では TFP 上昇 率は $0.9 \%$ 以下となっている。 また生産性に関連した 稲作生産行動の地域間格差の要因について, 孫・吉田 ［7］は地域労衝市場（兼業の機会）や農作業における
機械化の進展状況の相違などを挙げている.

\section{引用文献}

[1] 土井時久「稲作労働生産性の上昇とその要因分 析」, 崎浦誠治編著『経済発展と農業開発』, 農 林統計協会, 1985 年, pp.174-192.

[2]速水祐次郎・神門善久『農業経済論 新版』, 岩波書店, 2002 年, p.124.

[3] 甲斐諭「米生産削减の産業連関分析と大規模稲 作経営の課題」, 黒柳俊雄・嘉田良平編『米自 由化の計量分析』, 大明堂, 1996 年, pp.52-68.

[4] 近藤功庸・山本康貴「減反開始期以降における わが国稲作生産性の停滞とその要区一 Malmquist 生産性指数分析加らの接近一」, 『2003 年度日本農業経済学会論文集』（2003 年 11 月), pp.355-359.

［5］草苅仁「稲作の技術進歩と収量変動」, 崎浦誠 治編著『経済発展と農業開発』, 農林統計協会, 1985 年, pp.193-213.

[6] 新谷正彦「農業生産関数の計測 : 展望」,『農林 業問題研究』第 26 巻第 3 号 (1990 年 9 月), pp.34-41.

［7］孫噎・吉田昌之「稲作の生産行動の地域性一東 北および近畿地域一」, 『農林業問題研究』第 34 巻第 4 号 (1999 年 3 月), pp.29-35. 